\title{
Model and Pattern Contextualization Domestic Violence*
}

\author{
Ahmad Mukri Aji ${ }^{1}$ \\ Universitas Islam Negeri Syarif Hidayatullah, Jakarta, Indonesia
}

DOI: $\underline{10.15408 / \text { sjsbs.v5i2.9415 }}$

\begin{abstract}
:
Domestic violence is a phenomenon that often occurs in any part of the world. The biggest victims are women who are wives, children and parents in the category of second-level victims. Any religion forbids a person to commit violence against fellow humans, especially against someone who should be protected. This study elaboratively wants to examine how models and patterns of violence in households are contextually. In addition to being examined the obligations of the government in finding solutions to solutions, both legal solutions and other alternative solutions.
\end{abstract}

Keywords: Model, Pattern, Violence

\begin{abstract}
Abstrak:
Kekerasan dalam rumah tangga merupakan fenomena yang masih kerap terjadi di belahan dunia manapun. Korban terbesar adalah wanita yang berstatus sebagai istri, sedang anak-anak dan orang tua dalam katagori korban level kedua. Agama manapun melarang seseorang melakukan kekerasaan terhadap sesama manusia, apalagi terhadap seseorang yang seharusnya dilindungi. Kajian ini secara elaboratif ingin mengkaji model dan pola kekerasaan dalam rumah tangga secara kontekstual. Selain juga dikaji kewajiban pemerintah dalam mencari solusi penyelesaiannya, baik solusi hukum maupun solusi alternatif lainnya.
\end{abstract}

Kata Kunci: Model, Pola, Kekerasan

*Accepted: 11 April 2018, Revised: 23 April 2018, Accepted: 21 Juni 2018.

1 Ahmad Mukri Aji is a permanent lecturer of Shariah and Law Faculty, State Islamic University (UIN) Syarif Hidayatullah Jakarta. E-mail: mukri.aji@uinjkt.ac.id. ORCID ID: https://orcid.org/0000-0002-9802-5630, SINTA ID: 6666004. 


\section{Introduction}

Building a household without violence in a plural society that has different customs is convenient. Even a person's level of education is also become a benchmark for doing or not committing harshness. Because with the high level of education someone will make it able to control themselves and emotions. So the temperament that is seen is the akhlaqul karimah, patient and polite. The husband who is not rude leads the household, the patient wife who serves the husband, the father and mother who gently educate their children, and a polite man who is respecting other people who live in his house. Everything goes without violence, both physical and psychological. So what arises is comfort and peace.

Households that have been internally sturdy are still faced with various external challenges. Therefore, many things must be considered, if you want to build a healthy home. There are husband and wife personality factors, there is a socio-cultural climate that surrounds, neighbors, and no less urgent is the physical facilities of residential buildings that become residential. All of these become knick-knacks that significantly contribute to how the format of an Islamic household is formed.

The phenomenon that occurs in the community today is the number of acts of hardness committed by family members to other family members within the scope of one house. So that it results in the loss of household harmony. The most prevalent violence is violence committed by a husband on his wife or vice versa. Even though any form and motive, committing acts of violence from someone to another person, from a group to another group is a deviant behavior, and cannot be justified according to social norms.

\section{Terminology of Violence}

All forms of violence almost certainly are destructive and do not heed the rationality of the human mind, and even tend to deny the existing value system. Violence is indeed not an integral part of the character of the Indonesian people, but violence is still often used by some people in the practice of life, including in married life.

According to the Big Indonesian Dictionary, violence is something that is nature and hard characterized. ${ }^{2}$ It is also interpreted as an act of a person or group of people that causes injury or death of another person or causes physical damage or other people's things that are done by force.

2 Tim Penyusun, Kamus Bahasa Indonesia, (Jakarta: Pusat Bahasa Departemen Pendidikan Nasional, 2008), p.698. 
The definition of violence in social sciences has two main understandings. First, it is interpreted as all occurrence whose main elements are using threats or using violence. Second, interpreted as "any avoidable impediment to selfrealization" means everything that causes people to be hindered from actualizing their own potential naturally. ${ }^{3}$

Violence is an act that is done intentionally or intends to hurt another person. There is a burden of suffering arising from victims of violence, sometimes even causing prolonged trauma. Fear and pessimism to do something.

According to the 4th United Nations World Conference of women it was stated that violence is any action that results in physical, sexual or psychological misery or suffering, including threats of certain acts, coercion or deprivation of arbitrary liberty, whether that occurs in public or in life personal. ${ }^{4}$

Strength definitions, as the results of the 4th World Conference of women, in 1995 included:

1. Physical and psychological violence that occurs in the family includes beatings, sexual violations of girls in the household, violence related to dowry, rape in marriage, destruction of female genitals and traditional practices that harm women, violence committed by non-husbands wife and violence related to exploitation.

2. Physical, sexual and psychological violence in public, including rape, sexual violations, sexual harassment, trafficking in women and forced prostitution.

3. Physical, sexual and psychological violence committed is forgiven by the state, wherever it occurs. ${ }^{5}$

The point is that violence is a form of deviant treatment that results in other people being injured and hurt. Violence can be interpreted by persecution, which is an act done intentionally to cause pain or injury to the body of another person.

Violence in English is termed "violence". Etymologically, the word violence is a combination of the word "vis" which means power or strength and "latus" which comes from the word "ferre" which means to bring. So what is meant by violence is to bring strength. ${ }^{6}$

3 Ahmad Hufad, Perilaku Kekerasan: Analisis Menurut Sistem Budaya dan Implikasi Edukatif, dalam Jurnal Mimbar Pendidikan, Vol. XXII, No. 2 tahun 2003. p.51

${ }^{4}$ Refer to: the fouth woman world conference, 1995.

${ }^{5}$ Syufri, "Perspektif Sosiologis Tentang Kekerasan Terhadap Perempuan Dalam Rumah Tangga," dalam Jurnal Academica, Fisip Untad, VOL. I, 2009, h. 98. (Also see: Konferensi Dunia ke4 tentang wanita, 1995).

${ }^{6}$ Marsana Windu, Kekuasaan dan Kekerasan Menurut Johan Galtung, (Bandung: Kanisius, 1971), p.62. 
Saraswati ${ }^{7}$ stated that violence is a form of action taken against other parties, whether done by individuals or more than one person, which can cause suffering to other parties, both physical violence resulting in death, and psychological violence that does not affect the victim's physical, but results on the emergence of prolonged trauma in the victim.

According to the explanation of article 351 of the Criminal Code ${ }^{8}$ the abuse or violence is carried out intentionally to the detriment of the health of others, in addition to being done intentionally to give suffering to others.

In terminology violence is a condition and personality destroys human life. At the time of committing violence the offender as a minded and noble man becomes mired in animalistic traits. He will damage, suppress, extort, rape, terrorize, steal, kill, and destroy which in essence his actions are actions that tarnish and destroy the glory of himself as a noble human being. ${ }^{9}$

Violence can occur when someone acts in inappropriate ways and uses physical force that violates the law and hurts himself, others or the environment. Violent acts committed are consequences and manifestations of the soul and heart that are chaotic because of the shock, thus defeating common sense. The perpetrator of violence is only influenced by his lust and is focused on his own will regardless of others. ${ }^{10}$

\section{Types of Violence ${ }^{11}$}

Violent actions that often occur around us are seen from their types can be clarified into four types, namely, direct violence, inrect violence, refressive violence, and alienating violence. ${ }^{12}$

Direct violence is carried out by a group of actors to other parties (violence as action). Violence is directly carried out by a person or group of people using tools of violence. Indirect violence is something that happens in a structure (violence as structure). In indirect violence the perpetrator does not

\footnotetext{
${ }^{7}$ Rika Saraswati, Perempuan dan penyelesaian kekerasan dalam rumah tangga, (Bandung: Citra Aditya Bakti, 2006), p.66.

${ }^{8}$ Article 351 of the Criminal Code: (1). Persecution was punished with a prison sentence of two years and eight months or a fine of up to Rp. 4,500 (2). If the act causes serious injury, the victim is sentenced to jail for five years. (3). If the deed made the person dead, he was sentenced to seven years in prison. (4). With persecution it is likewise damaging the health of people intentionally. (5). The trial of committing this crime is not legal

${ }^{9}$ Haidar Nashir, Agama dan Krisis Kemanusiaan Modern, cet. II Juni, (Yogyakarta: Pustaka Pelajar, 1999), p.66.

${ }^{10}$ Abdurrahman Wahid, Islam Tanpa Kekerasan, (Yogyakarta: LKS Yogyakarta, 1998), p.142

${ }^{11}$ Ridwan, Kekerasan Berbasis Gender, (Purwokerto, Pusat Studi Gender STAIN Purwokerto, 2006), cet. Ke-1, p.57-64.

${ }^{12}$ Tim Komnas Perempuan, Peta Kekerasan, Pengalaman Perempuan Indonesia, (Jakarta: Ameepro, 2002), p.40.
} 
come into direct contact with the object. Indirect violence can be in the form of curbing, reducing or negating one's rights, intimidating, defaming, and terrorizing others. This type of violence is also called indirect violence. While structural violence just happens, it can be done because of local customs or culture.

First, the form of direct violence can be shaped; 1). A Murder like; Genocide/human extermination, Mass murder, Murder of individuals. 2) Brutal acts such as; torture, rape and persecution. 3). Physical restrictions/pressure, such as; moving from one population, forced eviction, kidnapping, hostage taking, imprisonment, and forced labor.

Second, the form of indirect violence can take the form of: Violation of the rights of human life, both in the form of violence due to habituation, the absence of protection from social violence, the absence of protection from natural violence, and violence with mediation.

Third, the form of Refressive violence can take the form of deprivation of fundamental rights. In the form of; social rights, trade unions or industry, social and gender violence, participation in social and economic life, protection of personal rights and social property rights, civil rights of citizens, and political rights.

Fourth, the forms of alientive violence can be; Deprivation of higher rights, habitat competition from the population, competition from social interaction (stigmatization), and ethnic formulation (ethnocida).

Based on the environment in which the incident occurred, violence can be divided into two, namely; violence experienced in the social environment and violence experienced in the family environment.

First; Violence experienced in the social environment, namely violence experienced by children in the social environment in the form of persecution or child abuse, specifically behaviors carried out by parents or adults against children and considered unnatural. Factors of child abuse are usually determined by the intensity of the behavior or action, the effect that is caused on the child, the assessment of the behavior or action, and the standards by which the assessment is carried out. Some people think that the perpetrators of child abuse are psychologically ill people. There are also those who think that persecution is caused by a factor of parental dissatisfaction, giving rise to anger and a lack of self-control which leads to persecution of children.

Second; Domestic Violence. Violence experienced in the family is violence that is received by children from their parents, either in the form of physical or mental violence. In general, family violence received by children occurs when there is abuse of violence by those who feel they have more power. Usually this violence is carried out by a mother or father to her child who is considered to 
have made a mistake, or by a husband to his wife because it is considered doing something that is not desired by the husband.

The various meanings above give us an idea that violence is an act or activity carried out intentionally or arbitrarily, accompanied by a threat or not, which causes suffering to others, both physically and mentally and harms others. Violent behavior that occurs in the family environment is better known as domestic violence or domestic violence, which is legally considered a criminal offense.

\section{Subjects and Objects of Domestic Violence}

When viewed from the subject and object, domestic violence can occur in the following context: ${ }^{13}$

\section{Husband's violence against his wife}

It cannot be denied, that the victims of the greatest violence are women who are wives. On the basis of marital status, often a man with the status of a husband presses his wife from various aspects. Both psychologically and physically. Thus resulting in prolonged trauma and fear from his wife. As a result there is no happiness at all from a wife who lives in this condition.

Addressing this matter, Secretary of the United Nations Boutros Boutros Ghali at the 4th World Women's Conference in Beijing in December 1993, said: "The struggle for women's rights, and the task of creating a new United Nations, can promote peace and the values which are nurture and sustain, are one and the same. Today - more than ever - the cause of all humanity. "14

According to him violence against women is a universal problem that must be universally condemned. This problem continues to get worse, especially in cases of domestic violence. Studies in ten countries show that 17-38 percent of women are victims of physical abuse by their partners.

At the general assembly of the United Nations explicitly acknowledged the increasingly alarming violence against women, the "Declaration of the elimination of violence against women was raised."15 This declaration produced 2001), p.77.

${ }^{13}$ Cahyadi Takariawa, Pernak-pernik Rumah Tangga Islami, (Surakarta: Era Intermedia,

14 Secretary-General, in International Women's Day message, sys promotion and protection of women's rights central to work of United Nations". un.org (WomenWatch). 1993. Retrieved 24 February 2010.

15 The international recognition that women have a right to a life free from violence is a recent one. Historically, their struggles with violence, and with the impunity that often protects the perpetrators, is linked with their fight to overcome discrimination. Since its founding the United Nations has concerned itself with the advancement of women's rights. [Ending Impunity for Violence Against Women and Girls". United Nations Department of Public Information. March 2007. Retrieved 2010-01-03]. 
several resolutions including the definition of violence against women itself, namely:

Article One: "For the purposes of this Declaration, the term "violence against women" means any act of gender-based violence that results in, or is likely to result in, physical, sexual or psychological harm or suffering to women, including threats of such acts, coercion or arbitrary deprivation of liberty, whether occurring in public or in private life."

Article Two: "Violence against women shall be understood to encompass, but not be limited to, the following: (a) Physical, sexual and psychological violence occurring in the family, including battering, sexual abuse of female children in the household, dowryrelated violence, marital rape, female genital mutilation and other traditional practices harmful to women, non-spousal violence and violence related to exploitation; (b) Physical, sexual and psychological violence occurring within the general community, including rape, sexual abuse, sexual harassment and intimidation at work, in educational institutions and elsewhere, trafficking in women and forced prostitution; (c) Physical, sexual and psychological violence perpetrated or condoned by the State, wherever it occurs. ${ }^{16}$

In the declaration three areas were identified where violence against women often occurred, one of which was in the family. In this context, the declaration provides limits: "Physical, sexual and psychological violence that occurs in the family, including beatings, sexual abuse of girls in the household; violence related to dowry; rape in marriage, destruction of female genitals; violence, and other traditional practices that endanger women, violence by family members not partners; and violence related to the exploitation of the body and human power (especially children and women)."

It turns out that acts of domestic violence occur almost in every country, both in developed countries and developing countries, and are cross-religious and cultural in nature. Records of cases of violence against women in the United States, for example, provide data that every 18 minutes a woman experiences a beating. Domestic violence has been considered to be the main cause of injury to groups of productive age women in the United States. In fact, between $22-23 \%$ of women who enter hospital emergency rooms in the United States are due to domestic violence.

In some cases in Muslim families there are often several acts of husband's violence against his wife in the form of a husband's rape of his wife. It was said to commit rape because the husband forced his wife to have sexual relations, even though his wife was menstruating or was fasting for Ramadhan.

In this case, it seems that the husband does not understand or pretends not to understand about family laws. Islam forbids associating wives in

16 The Declaration on the Elimination of Violence Against Women was adopted without vote by the United Nations General Assembly in its resolution 48/104 of 20 December 1993. 
menstruation, even being punished as forbidden. Islam also prohibits the relationship of husband and wife during the day of the month of Ramadan when both are status as people who are obliged to fast. Violations of this matter are subject to expulsion (legal fines) that is the perpetrator is required for 2 consecutive months without even stopping one day. When a husband forces his wife to have sexual relations in a state of menstruation or fasting during the month of Ramadan, it is clear this is a form of rape from a husband against his own wife.

Ironically, when the wife tries to advise directly or through other people, her husband spills anger in the form of heavier physical violence. Until finally, the wife asked for divorce from her husband, but the husband did not want to divorce her. Even the husband threatened, if his wife still filed for divorce through courtesy, he would do even more cruelly such as kidnapping or persecuting his children. Under these conditions, again the position of women was cornered. So that nothing can be done except surrender to the months of domestic violence.

In another example, the husband feels entitled to express his will to the wife because he is a leader in the household. The implication that arises is the behavior of tyrants and arbitrariness of husbands towards their wives and children. He is 'king' in a household free from criticism and lack. As if he is everything, while the other party is only a follower, and is fully dependent on him. It is not uncommon for a head of household to beat his wife and children or aides, for simple reasons. In examples of cases such acts occur in Muslim families, giving rise to the impression that such is the teaching of Islam which places men as absolute rulers. Even though the essence is not so.

\section{Wife Violence Against Husband}

Although rarely found, but domestic violence can also occur from the wife to the husband. A wife who is very jealous and angry, may express explosive anger in the form of acts of violence, both physically and mentally. Physically, for example, the wife hurts the husband with a knife or with hot water, even the wife kills the husband out of jealousy. Once, a wife cut her husband's genitals with scissors because of his jealousy.

Psychological violence occurs, for example when the wife throws harsh and dirty words at her husband. Wives terrorize husbands with threats and hurtful expressions. May the wife also take forced actions against her husband's property for which he has no rights. Including committing acts of sexual abuse or infidelity that are intentionally displayed in front of the husband's eyes. Such things are mental or psychological violence. 


\section{Parental Violence Against Children}

There have been many cases that children are victims of violence from their own parents. Physical violence occurs when parents often hit at their children. Only because of minor mistakes that are not principle, parents become emotional and punish children with crackdown. It is not uncommon to find children who become disabled for life because of torture by their parents, or even result in death due to persecution by their parents.

In the KPAI notes published on its website, children who were victims of physical violence such as abuse, in the 2011-2016 period reached 920 cases. The most cases occurred in 2014, reaching 273 cases. Whereas children who were victims of six years of murder were recorded to reach a total of 358 cases. Cases of parental violence against children, according to KPAI, are motivated by family disharmony, economic factors, lack of knowledge about childcare, and personal problems that lead to mental health. ${ }^{17}$ Educational background is not a determining factor for violence against children.

In addition to acts of physical violence against children, also acts of immoral violence against children are often done by adults. So that children become confined to their childhood. There is no more happiness for children, there is only pressure and intimidation which is a scary thing in everyday life.

There are also some parents who commit violence on children with motives to educate. Educating by means of violence is good intention but done in a bad way. The impact will certainly be bad for the child in the future. Therefore, any form of violence will have a negative impact on the child. So, violence as an alternative solution that is used by someone in carrying out their obligations as parents cannot be easily applied, but must be through careful consideration, both in terms of causes, factors of parents, children or the environment and more importantly is the result of will be caused by these actions, so that by paying attention to all of that then acts of violence against children can be avoided. ${ }^{18}$

Thus, solving problems related to children through violence is not a solution. Even if it has to be done, it must not exceed the limit, resulting in the child being injured. Because this is an act of violence that is immoral, violates human rights, and certainly will have psychological consequences for children in the future.

\footnotetext{
${ }^{17} \mathrm{http} / /$ /bankdata.kpai.go.id/tabulasi-data/data-kasus-per-tahun/rincian-data-kasusberdasarkan-klaster-perlindungan-anak-2011-2016

${ }_{18}$ Maisaroh, "Kekerasan Orang Tua Dalam Mendidik Anak Perspektif Hukum Pidana Islam," IN RIGHT, Jurnal Agama dan Hak Azazi Manusia, Vol. 2 No. 2 Mei 2013, p.276.
} 


\section{Violence of Children against Parents}

There were also many children who were perpetrators of violence, both physically, sexually and psychologically towards their parents. Starting from differences of opinion, or from desires that are not followed, or from unfair treatment from their parents, so that children become angry and persecute their own parents, some even cause the death of parents.

Sexual violence has been reported, boys raped their own biological mothers. While psychological violence is very much an example in the social life of our society. Children blaspheme, denounce, say rude and dirty to their parents. Children threaten to run away from home, threaten to harm their parents, and various other threats. Such children want to impose their own will on parents.

In some countries, such as in the United States and Japan, according to research, several parties have shown that the number of child violence against parents is large. According to the US Department of Justice, in 1980, it was estimated that in 1.2 million cases, 47,000 of them were child violence against parents. Violence committed by children against parents is not only limited to beatings, it has even reached the level of murder. From 1977 to 1986, one in eleven families worldwide, children killed their parents. ${ }^{19}$

In Japan in the late 1970s this problem was highlighted by the public, when Japan was in a post-high economic period. According to Japanese Police data, cases of violence against parents each year reach 1,000 cases. Community attention began to appear after the emergence of the following three cases, namely in 1967, a class 1 high school student known as an accomplished child, quiet and never acting at school, committing violence to his mother, because he was upset with his mother who always told him to study; followed in 1980, a child who took the entrance examination for 2 years, for failing a college entrance examination, killed his parents who were sleeping using a baseball bat; and in 1981, a grade 3 student, who was known as an accomplished child, hit his mother, because he always compared with his much smarter brother, he lived in a family of civil servants who were concerned about educational matters.

These three cases received attention from the public because they had two things in common. First, it is carried out by teenagers who are known as ordinary children or quiet children, diligent and achievers in school and those who are victims are family members. ${ }^{20}$

Based on Japan's national survey, 80 percent of the violence carried out by children against parents is carried out by boys aged 15-24 with an economic

\footnotetext{
${ }^{19}$ Richard J Gelles. Intimate Violence in Families. (United States: 1997), p.110-111.

${ }^{20}$ Fumie Kumagai. Unmasking Japan Today:The Impact of Traditional Values on Modern Japanese Society. (USA, 1996), p.86.
} 
background in middle to upper class parents. ${ }^{21}$ The number of Japanese domestic violence in 1980 reached a total of 1025 cases. Within this figure, 61.3 percent is violence committed against mothers and 15.9 percent of violence against fathers, and the remainder is violence against other family members..$^{22}$

\section{Harshness against Household Assistant}

Domestic violence does not only occur in family members, but can also occur with household assistant who work for the family. Violence against servants in Indonesia is indeed not as big as what happened in other countries, such as in Saudi Arabia which according to some sources reported the number of cases of violence against domestic servants, both those from Indonesia and from other countries. Violence that occurred in the form of persecution, rape, immoral acts, unpaid salaries, and so on.

According to information sourced from the embassies of several countries sending domestic migrant workers to show thousands of domestic labor complaint cases, although different according to the Ministry of Manpower and Social Affairs of Saudi Arabia, which stated that the rate of violations was only a small proportion of the majority who worked..$^{23}$

The cause of the many acts of violence against household assistant in the country of Saudi Arabia is due to the many opinions of Saudis who still believe that a servant is the same as a slave who can be treated by any employer. This perception is influenced by slavery-era ideologies that have not been completely lost. No wonder the BNP2TKI Crisis Center collects many cases in the two-year period. There are six models of violence against servants who are often experienced by migrant workers, such as unsuitable employment, work agreements, unpaid salaries, persecution, sexual harassment, workplace illness, and unilateral layoffs. Figures show a high number but gradually decline from year to year, this is in line with the enactment of a moratorium on the sending of migrant workers to Saudi Arabia. ${ }^{24}$

${ }^{21} \mathrm{Ibid}$

${ }^{22}$ Fumie Kumagai. "Filial Violence:A Peculiar Parent-Child Relationship in The Japanese Family Today." 1980.

${ }^{23}$ Refer to: Data taken from Human Rights Watch, 2009.

${ }^{24}$ Rizka Puspitasari, "Analisis Penyebab Praktik Kerja Paksa Di Arab Saudi: Fenomena Kerja Paksa Terhadap Tki Informal (2011-2014)," Journal of International Relations, Volume 2, Nomor 3, Tahun 2016, p.215-216. 


\section{Kinds of Household Violence}

The types of household violence that have developed in the community according to Hasbiyanto (1998) have four types, namely:25

1. Sexual violence, such as forcing sexual intercourse, forcing one's own sexual tastes, not paying attention to the wife's satisfaction.

2. Physical violence, such as hitting, slapping, spitting, grabbing, kicking, lighting with cigarettes, hitting, injuring with goods/weapons.

3. Economic violence, such as not given shopping money, using or spending wife's money.

4. Emotional violence, such as denouncing, insulting, threatening or frightening as a means of forcing the will, isolating the wife from the outside world. ${ }^{26}$

Unlike the case according to the Law on the Elimination of Domestic Violence there are four types of household violence, ${ }^{27}$ namely:

1. Physical violence is an act that results in pain, falling sick or seriously injured. In the context, the forms of physical violence experienced by women victims include, among others: slap, beating, snatching, trampling, kicking, strangulation, throwing hard objects, throwing using sharp objects, such as knives, scissors, ironing and burning. Whereas in the context of social relations, physical violence against ordinary women is in the form of confinement or rape of female maids by employers or genital mutilation which is carried out in the name of certain cultures or beliefs.

2. Psychic Violence is an act that results in fear, loss of self-confidence, loss of ability to act, feeling helpless, and or or severe psychological suffering in someone. The psychological forms of violence experienced by women include invective, ongoing humiliation to minimize the dignity of the victim, the shouting and threat that is intended to create fear. In general, psychological violence occurs in the context of personal relationships.

3. Sexual violence is the forced sexual relations of people who live in the household or forced sexual relations with one person within the scope of their household with another person for a particular purpose. Sexual violence includes various behaviors that are unwanted and have sexual significance, or often called "sexual harassment", as well as various forms of forced sexual relations which are often referred to as rape.

${ }^{25}$ Hasbianto, E.N. Kekerasan Terhadap Istri. Makalah Seminar Nasional “Dibalik Harmoni Rumah Tangga: Kekerasan Terhadap Istri", Yogyakarta, 28 November 1998.

26 Sri Meiyeti, Kekerasan Terhadap Perempuan dalam Rumah Tangga, (Yogyakarta, Pusat Penelitian UGM, 1999) p.6.

${ }^{27}$ Laws of the Republic Indonesia Number 23 in year 2004. 
4. Household neglect, means that a person does not carry out his legal obligations to a person in the household in the form of neglecting to provide obligations for life, care or maintenance to that person. Included in the category of neglect of the household is giving restrictions or prohibiting someone to work properly inside or outside the home so that the victim is in the control of that person.

The various types of violence as stipulated in the law on the Elimination of Domestic Violence are a reflection of various forms of violence that often occur and become a common phenomenon among the community. For this type of physical violence, the process of proof is very easy by referring to the provisions in criminal law (the Code of Criminal Law) with clear benchmarks. Whereas for the type of psychological violence and neglect of the household the process of proof is indeed difficult because it is related to subjective feelings or emotions. Here a prosecutor and judge are challenged to formulate it so that it is considered as an act that belongs to the category of violence.

As for the types of sexual harshness, indeed in terms of applicable law in Indonesia (criminal) it is not known as sexual violation and this is with foreign legal literature that is familiar with the term sexual violece. In the Criminal Law, ${ }^{28}$ only the term crime against decency is contained in book II chapter XIV covering articles 281-303 and in book III chapter VI includes articles 532-547 concerning violations of decency. Thus, in addition to physical violence, law enforcement officials are required to provide concrete interpretations so that an act is truly considered a criminal offense.

In the Criminal Code, the definition of crimes relating to violence against women generally assumes women as human beings are weak and parallels the position of boys, as stipulated in article 297. Other assumptions are that husbands are protectors of women, while wives are obliged to always obedient to the husband's sexual will. This is very evident in the definition of rape. Article 285 states that "anyone who violently forces intercourse with a woman who is not his wife will be prosecuted with rape." This definition certainly does not clarify the act of rape in a marriage bond (husband to his wife) or marital rape as a crime. Likewise sexual violence on children (incest) is still categorized as obscene acts (not rape), which are of course lighter legal sanctions. ${ }^{29}$

Referring to the Criminal Code above, violence against women is defined as a "crime against decency" and not as a crime against women as the owner of his body. The definition of decency and the Code of Criminal Law refers more to the morality of the community and not to provide protection to women. In the Ke-2.

${ }^{28}$ Moeljatno, Kitab Undang-undang Hukum Pidana, (Yogyakarta: Bumi Aksara, 2003), Cet.

${ }^{29}$ Rita Serena Kolibonso, :Kekerasan Itu Bernama Kekerasan Rumah Tangga" Perempuan No. 26 Tahun 2002, p.18. 
articles on crime against decency, women are tasked with maintaining and at the same time being a measure of public morality. In other words, the basis of his view is that if the woman is good, the morality of the community will be maintained.

According to the records of the National Commission on Violence Against Women, based on reports from the accompanying team, shows that cases of violence against women can occur in the victim's own work place, in speeches or public events or at the victim's own place, in public ceremonies or events. While based on the experience of women victims of violence shows that the perpetrators of violence in general are their own husbands, fathers, other family members, or victims' employers.

The fact that is clear from this picture is that the perpetrators of female violence actually came from parties who were trusted by the community to act as protectors and protectors of women. This is for husbands, fathers, employers, and in the context of the State, government security forces. Here it is revealed clearly that, in the relationship between the giver and recipient of protection, who they are, there is always a very striking relationship of power, that is, the protection provider is in a stronger and more powerful position than the recipient of protection. It is unequal power relation which later becomes one of the roots of the birth of violence..$^{30}$

\section{Government Efforts to Reduce Domestic Violence}

In the framework of implementing the Law on the Elimination of Domestic Violence, all elements of the nation are collectively obliged to participate in overseeing the provisions of the provisions in the Law on the Elimination of Domestic Violence. In chapter V, articles 11-15 are regulated about the obligations of the government and the community in the context of preventing domestic violence. ${ }^{31}$

Community participation in preventing the occurrence of acts of domestic violence is basically based on public awareness that this violent behavior is a crime that can endanger the peace and tranquility of society in general. To foster this awareness a system of values is needed which produces standards for psychological processes. Such thinking patterns determine the mental attitude of the community. This mental attitude is essentially tendencies to behave, form

\footnotetext{
${ }^{30}$ Ridwan, Kekerasan Berbasis Gener, (Purwokerto, Pusat Studi Gener STAIN Purwokerto, 2006), cet. Ke-1, p.80-90.

${ }^{31}$ Laws of the Republic Indonesia Number 23 in year 2004.
} 
behavioral patterns and rules. ${ }^{32}$ Behavioral patterns which then participate consciously prevent acts of violence in the surrounding community.

The obligations of the government in efforts to eliminate articles of domestic violence article 11-12 are as follows:

1. Formulate a policy on eliminating domestic violence;

2. Organizing communication, information and education about domestic violence;

3. Organizing socialization and advocacy on domestic violence;

4. Organizing gender-specific positive education and training and issues of domestic violence and setting gender-sensitive service standards and accreditation.

For the implementation of services for victims, in article 13 the government and regional government in accordance with their respective functions and tasks can make several efforts, namely:

1. Provision of a special service room at the police station;

2. Provision of officials, health workers, social workers and spiritual guides;

3. Making and developing systems and mechanisms for cooperation in service programs involving parties that are easily accessible to victims; and

4. Providing protection for escorts, witnesses, families and friends of victims.

The obligation of the community in the effort to eliminate domestic violence as stipulated in article 5 states that: anyone who hears, sees, or knows about the occurrence of domestic violence is obliged to make efforts in accordance with the limits of his ability to: Prevent the occurrence of criminal acts; Providing protection to victims; Provide emergency assistance; and Assist the process of submitting a request for protection.

\section{Conclusion}

From the discussion above, it can be concluded that some conclusions are related to acts of domestic violence, including:

First; The subject and object of domestic violence consists of five things, namely: Husband's violence against the wife; Wife Violence Against Husband; Parent Violence Against Children; Violence of Children against Parents; Violence against Domestic Helpers.

32 Nur Rohim Yunus, Restorasi Budaya Hukum Masyarakat Indonesia, (Bogor: Jurisprudence Press, 2012), p.103-104. 
Second; In general there are four models or patterns of occurrence of domestic violence, namely; Sexual violence; Physical abuse; Economic Violence; and Emotional Violence. While according to the PKDRT Act there are four different types of models and patterns in domestic violence, namely; Physical abuse; Psychic Violence; Sexual violence; and neglect in the household.

Third; The efforts made by the government in reducing domestic violence are by implementing the PKDRT law, as well as providing services to victims such as providing special service spaces in the police station, providing officers, health workers, social workers and spiritual guides, making and developing systems and the mechanism of cooperation in service programs involving various parties, and providing protection for assistants, witnesses, families and friends of victims.

\section{Bibliography}

Data dari Human Rights Watch, 2009.

Ending Impunity for Violence Against Women and Girls" (PDF). United Nations Department of Public Information. March 2007. Retrieved 2010-01-03.

Gelles, Richard J. Intimate Violence in Families, United States: 1997.

Hasbianto, E.N. Kekerasan Terhadap Istri, Makalah Seminar Nasional "Dibalik Harmoni Rumah Tangga: Kekerasan Terhadap Istri", Yogyakarta, 28 November 1998.

http://bankdata.kpai.go.id/tabulasi-data/data-kasus-per-tahun/rincian-datakasus-berdasarkan-klaster-perlindungan-anak-2011-2016

Hufad, Ahmad. "Perilaku Kekerasan: Analisis Menurut Sistem Budaya dan Implikasi Edukatif," dalam Jurnal Mimbar Pendidikan, Vol. XXII, No. 2 tahun 2003.

Kolibonso, Rita Serena. "Kekerasan Itu Bernama Kekerasan Rumah Tangga" Jurnal Perempuan, No. 26 Tahun 2002.

Kumagai, Fumie. Unmasking Japan Today:The Impact of Traditional Values on Modern Japanese Society, USA, 1996.

Kumagai, Fumie. "Filial Violence: A Peculiar Parent-Child Relationship in The Japanese Family Today." 1980.

Maisaroh, "Kekerasan Orang Tua Dalam Mendidik Anak Perspektif Hukum Pidana Islam," IN RIGHT, Jurnal Agama dan Hak Azazi Manusia, Vol. 2 No. 2 Mei 2013.

Meiyeti, Sri. Kekerasan Terhadap Perempuan dalam Rumah Tangga, Yogyakarta, Pusat Penelitian UGM, 1999. 
Moeljatno, Kitab Undang-undang Hukum Pidana, Yogyakarta: Bumi Aksara, 2003, Cet. Ke-2.

Nashir, Haidar. Agama dan Krisis Kemanusiaan Modern, cet. II Juni, Yogyakarta: Pustaka Pelajar, 1999.

Puspitasari, Rizka. "Analisis Penyebab Praktik Kerja Paksa Di Arab Saudi: Fenomena Kerja Paksa Terhadap Tki Informal (2011-2014)," Journal of International Relations, Volume 2, Nomor 3, Tahun 2016.

Ridwan, Kekerasan Berbasis Gender, Purwokerto: Pusat Studi Gender STAIN Purwokerto, 2006, cet. Ke-1.

Saraswati, Rika. Perempuan dan penyelesaian kekerasan dalam rumah tangga, Bandung: Citra Aditya Bakti, 2006.

Secretary-General, in International Women's Day message, sys promotion and protection of women's rights central to work of United Nations". un.org (WomenWatch). 1993. Retrieved 24 February 2010.

Syufri, "Perspektif Sosiologis Tentang Kekerasan Terhadap Perempuan Dalam Rumah Tangga," dalam Jurnal Academica, Fisip Untad, VOL. I, 2009, h. 98.

Takariawa, Cahyadi. Pernak-pernik Rumah Tangga Islami, Surakarta: Era Intermedia, 2001.

The Declaration on the Elimination of Violence Against Women, United Nations General Assembly in its resolution 48/104 of 20 December 1993.

Tim Komnas Perempuan, Peta Kekerasan, Pengalaman Perempuan Indonesia, Jakarta: Ameepro, 2002.

Tim Penyusun, Kamus Bahasa Indonesia, Jakarta: Pusat Bahasa Departemen Pendidikan Nasional, 2008.

Undang-Undang Republik Indonesia Nomor 23 Tahun 2004.

Wahid, Abdurrahman. Islam Tanpa Kekerasan, Yogyakarta: LKS Yogyakarta, 1998.

Windu, Marsana. Kekuasaan dan Kekerasan Menurut Johan Galtung, Bandung: Kanisius, 1971.

Yunus, Nur Rohim, Restorasi Budaya Hukum Masyarakat Indonesia, Bogor: Jurisprudence Press, 2012. 
Ahmad Mukri Aji

196 - Fakultas Syariah dan Hukum UIN Syarif Hidayatullah Jakarta 